\title{
MODEL SISTEM PANAS BUMI BERDASARKAN DATA GRAVITY PADA DAERAH SONGA - WAYAUA, PULAU BACAN, MALUKU UTARA
}

\author{
Oleh: \\ Ahmad Zarkasyi dan Yuanno Rezky \\ Pusat Sumber Daya Geologi \\ Jin. Soekarno - Hatta No. 444 Bandung
}

SARI

Daerah panas bumi Songa-Wayaua merupakan salah satu area panas bumi yang menarik, yang berada di Pulau Bacan, Provinsi Maluku Utara. Manifestasi panas bumi di permukaan yang terdapat di Songa-Wayaua mempunyai temperatur berkisar $65-103,5^{\circ} \mathrm{C}$ berupa mata air panas, fumarol, kolam lumpur, tanah panas dan batuan teralterasi. Survei gaya berat yang dilakukan pada tahun 2006 bertujuan untuk mengindetifikasi sistem panas bumi dan area prospeknya. Pemodelan gaya berat dengan inversi 3 dimensi menunjukkan sistem panas bumi Songa-Wayaua terkonsentrasi di bawah struktur Graben Songa, di antara Bukit Lansa dan Bukit Pele.

Kata Kunci : Panas bumi,Songa-Wayaua, gaya berat, model.

\section{ABSTRACT}

Songa-Wayaua geothermal area is one of several interesting geothermal areas that located in the Bacan Island, North Maluku Province. Surface thermal features $\left(65-103,5^{\circ} \mathrm{C}\right)$ in the Songa-Wayaua area consist of hot springs, fumarole, mud pool, hot grounds, and altered rocks. Gravity surveys conducted in 2006 was intended to identify geothermal system and its prospect in this area. 3 D-inversion model from gravity a revealed geothermal system concentrated under Songa graben structure, between Bukit Lansa dan Bukit Pele.

Keyword: geothermal, Songa-Wayaua, gravity, model

\section{PENDAHULUAN}

Daerah Songa-Wayaua berada di Pulau Bacan, Kabupaten Halmahera Selatan, Provinsi Maluku Utara (Gambar 1). Pada tahun 2006, Pusat Sumber Daya Geologi melakukan eksplorasi panas bumi terpadu: geologi, geokimia dan geofisika. Metode gaya berat merupakan salah satu metode geofisika yang digunakan pada saat itu dengan asumsi metode ini cukup dalam untuk mendeliniasi struktur geologi berupa sesar maupun struktur batuan bawah permukaan berdasarkan perbedaan densitas batuan.

Pada suatu sistem panas bumi, fluida panas terakumulasi pada suatu lapisan bersifat poros yang disebut sebagai lapisan reservoir. Fluida panas ini tertahan oleh lapisan yang bersifat kedap air (lapisan penudung). Fluida panas ini dapat muncul ke permukaan sebagai manifestasi panas bumi, melalui kontrol struktur geologi berupa sesar. Sumber panas dan fluida panas dapat menyebabkan perubahan densitas massa batuan pada lingkungan di sekitarnya. Metode gaya berat akan memberikan gambaran bawah permukaan yang dapat digunakan untuk penafsiran struktur batuan bawah permukaan dan sesar yang digunakan sebagai jalur oleh fluida panas bumi menuju permukaan.

Pemodelan dalam geofisika adalah suatu proses estimasi model dan parameter model untuk menggambarkan kondisi bawah permukaan berdasarkan data amat di permukaan. Proses pemodelan dalam fisika dapat menggunakan teknik pemodelan ke depan (forward modelling) dan teknik pemodelan ke belakang (inverse modelling). 
Pada makalah ini diperlihatkan pemodelan inversi 3 dimensi untuk merepresentasikan kondisi bawah permukaan di daerah panas bumi SongaWayaua dengan menggunakan anomali gaya berat residual. Anomali gaya berat yang di sampaikan dalam makalah ini merupakan hasil proses ulang dari data gaya berat yang diambil pada tahun 2006 .

\section{REVIEW GEOLOGI DAN MANIFESTASI PANAS BUMI}

Berdasarkan pemetaan geologi yang dilakukan oleh Tim Survei Terpadu (Pusat Sumber Daya Geologi, 2006), daerah Songa-Wayaua dikelompokkan menjadi 15 satuan batuan yang terdiri dari batuan malihan berupa sekis amfibolit, sekis amfibolit kuarsa dan meta diorit, batuan

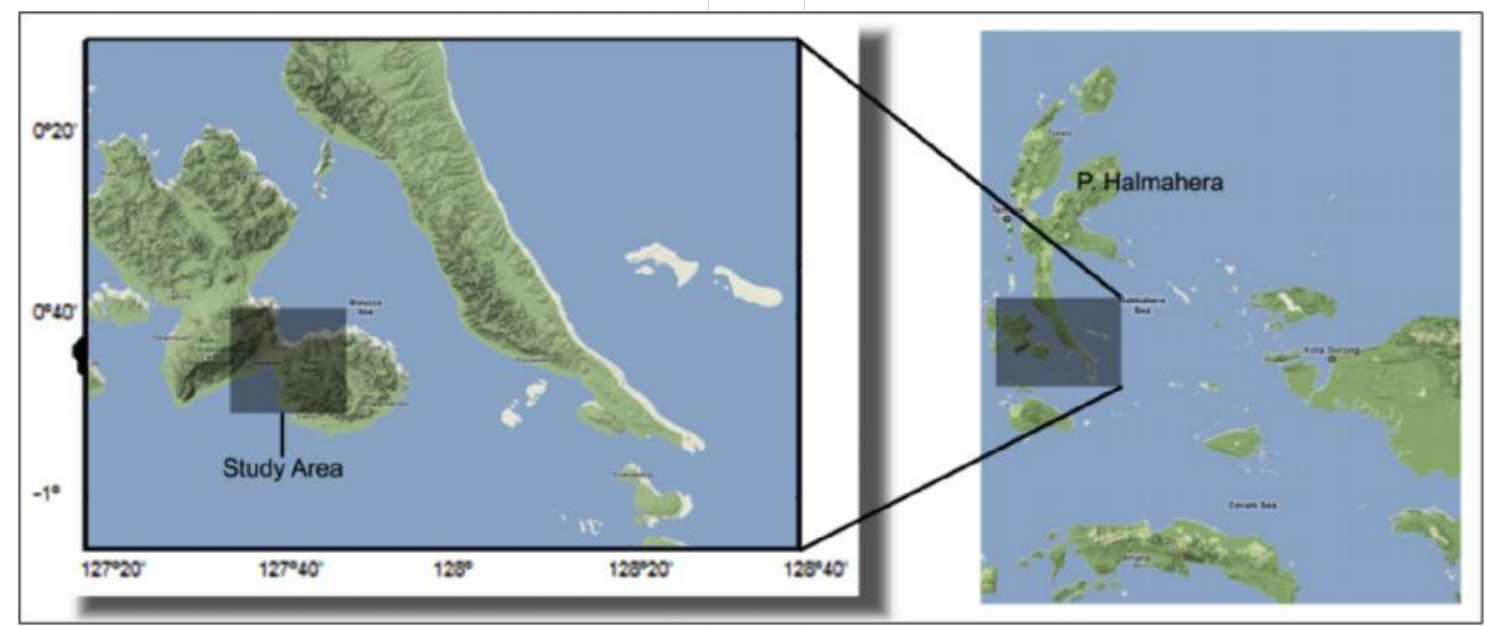

Gambar 1. Peta lokasi daerah panas bumi Songa-Wayaua

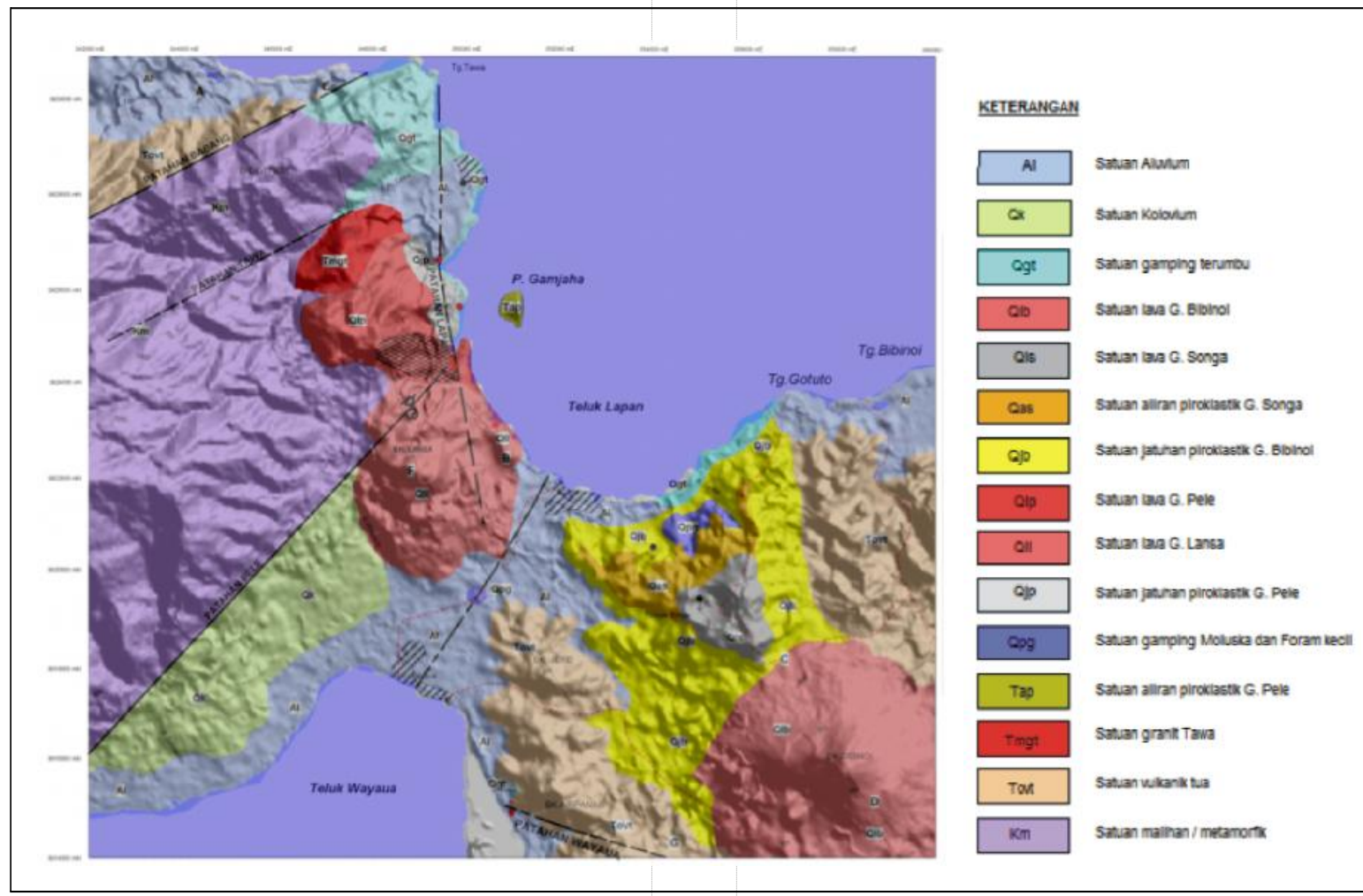

Gambar 2 . Peta geologi Songa-Wayaua (modifikasi dari peta geologi Songa-Wayaua dari Tim Survey Terpadu, 2006) 
sedimen berupa batugamping, batuan terobosan berupa granit, serta batuan vulkanik berupa lava dan piroklastik, dan endapan permukaan aluvium dan koluvium (Gambar 2). Batuan yang terpetakan berumur Kapur hingga Kuarter, (berdasarkan metode fission-track, lava Gunung Lansa (QII) berurnur 0,2 $\pm 0,0$ juta tahun (Plistosen Akhir)). Struktur geologi yang berkembang di daerah ini berupa kelurusan kerucut G. Bibinoi, G. Lansa/ G. Pele, danau kawah G. Songa, 4 kawah di G. Lansa, 2 struktur sesar timurlaut-baratdaya, 1 sesar utara baratlaut-selatan tenggara dan 1 sesar normal arah utara timurlaut-selatan baratdaya

Manifestasi panas bumi yang ditemukan di daerah ini berupa mata air panas, fumarol, kolam lumpur (mud pool), tanah panas dan batuan ubahan yang muncul di beberapa lokasi. Manifestasi panas ini tersebar di sepanjang dataran pantai dari daerah Songa sampai Tawa (manifestasi Pelepele Besar, Pelepele Pesisir, Padopado, Babale Lansa) dengan temperatur $45-103,5{ }^{\circ} \mathrm{C}$, sedangkan sebelah selatan dijumpai adanya mata air panas di pantai Wayaua dengan temperatur $65-69^{\circ} \mathrm{C}$.

\section{ANOMALI GAYA BERAT}

Data gaya berat yang dihasilkan berupa anomali Bouguer densitas 2,6 $\mathrm{gr} / \mathrm{cm} 3$. Filterisasi pada anomali Bouguer dilakukan untuk mendapatkan anomali

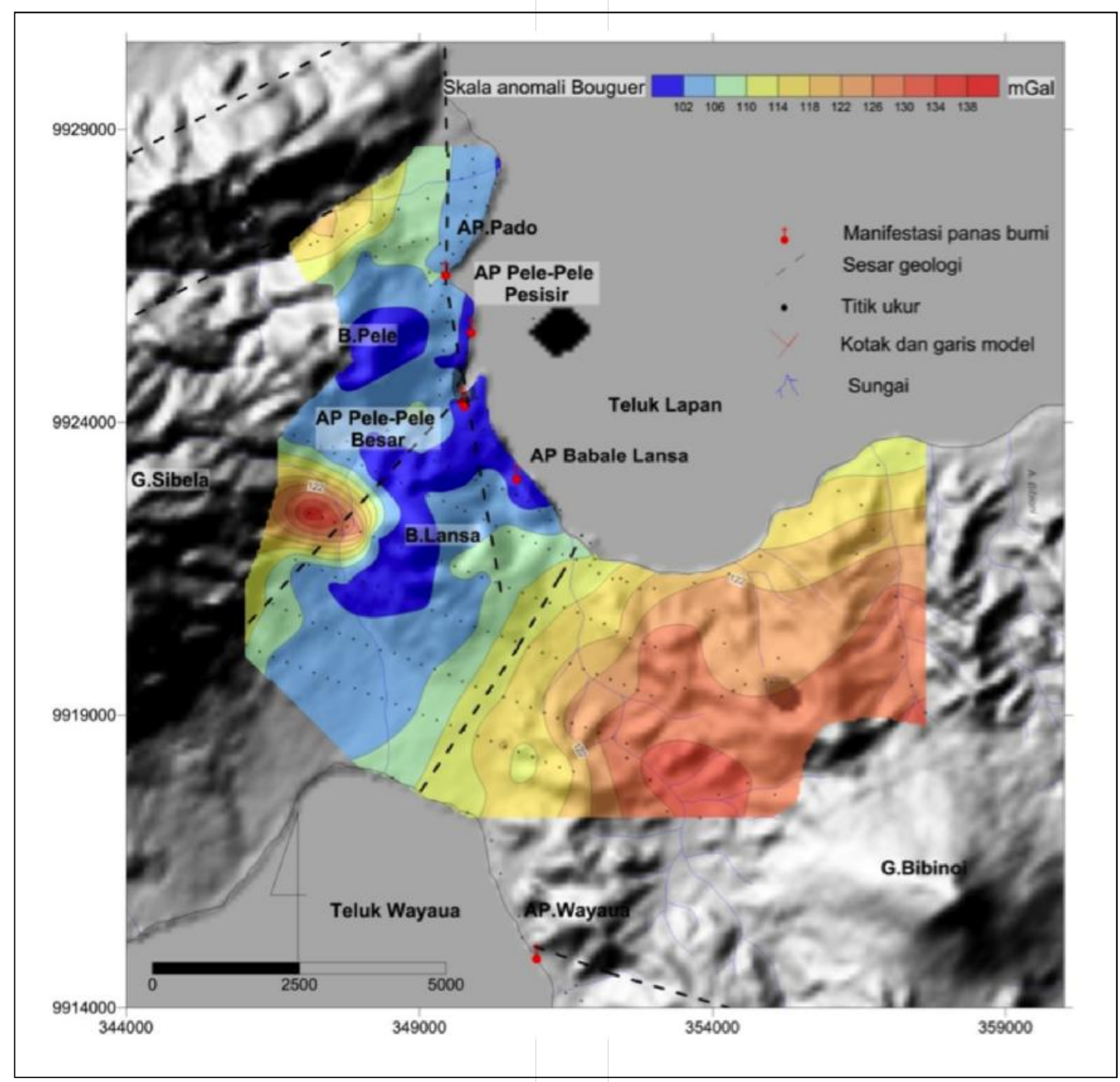

Gambar 3. Peta anomali gaya berat Bouguer daerah Songa-Wayaua 


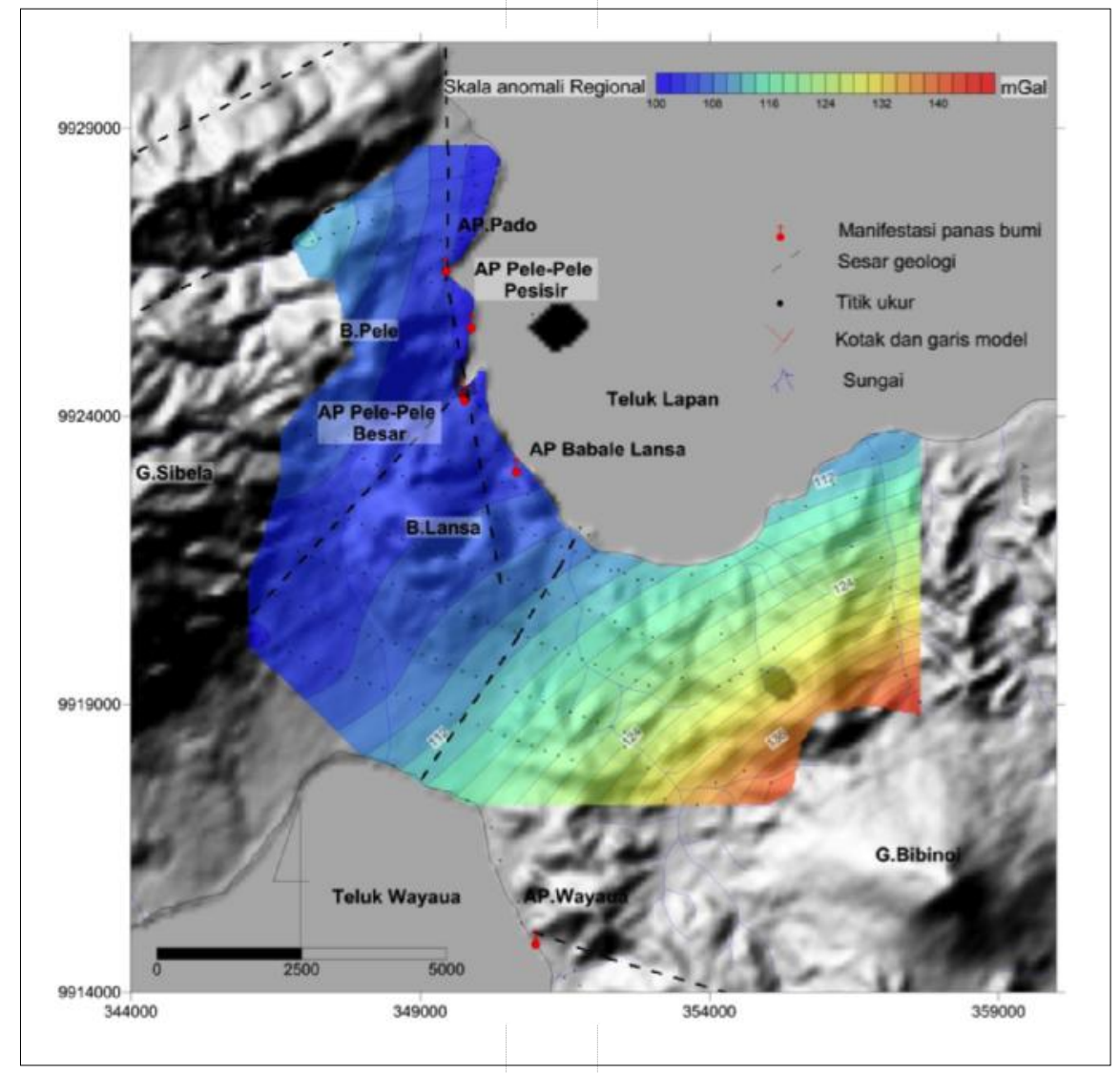

Gambar 4. Peta anomali gaya berat regional daerah Songa-Wayaua

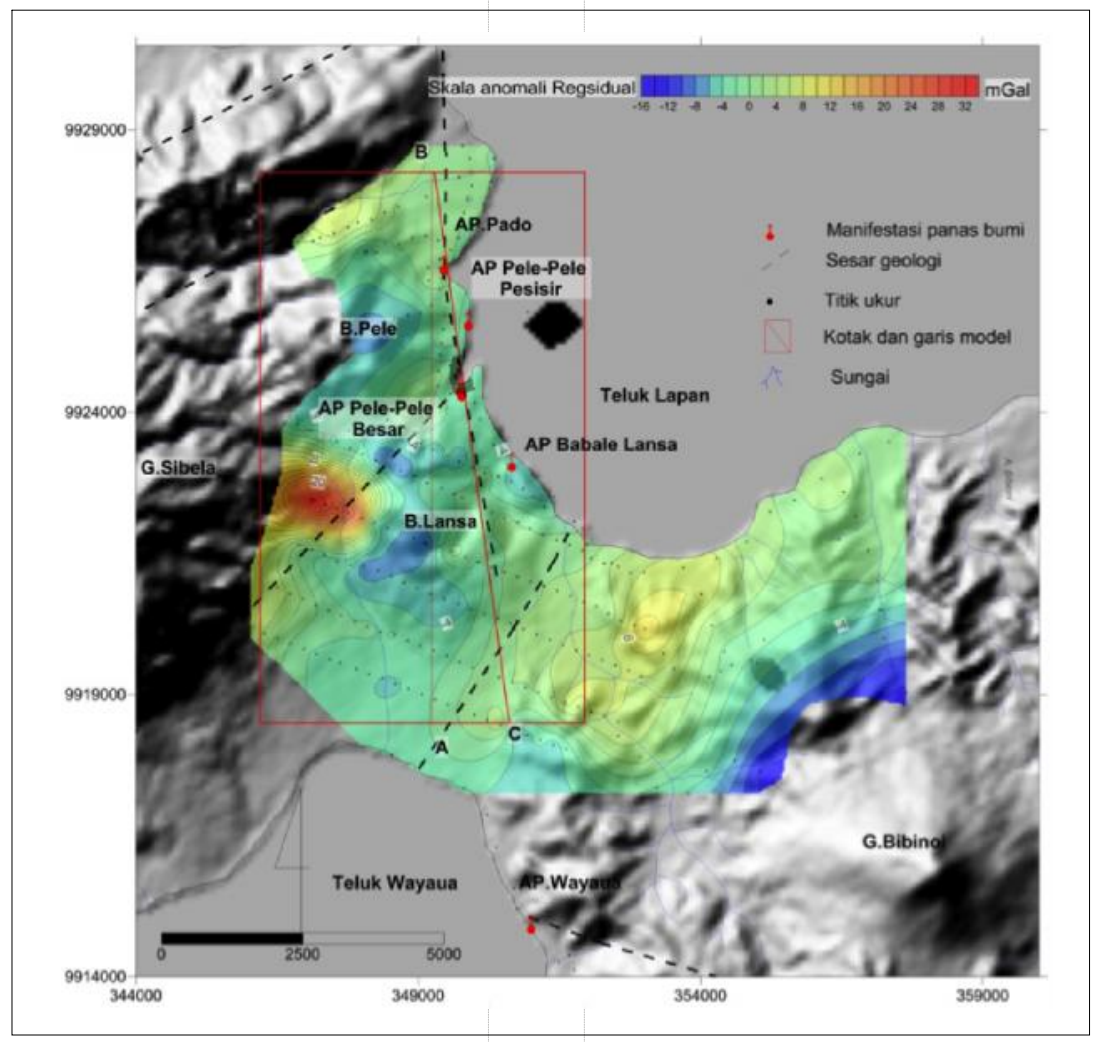

Gambar 5. Peta anomali gaya berat residual daerah Songa-Wayaua 
residual dengan menggunakan polinomial orde 2 menjadi anomali residual dan regional (Gambar 3, 4 dan 5).

Analisis pada peta anomali gaya berat Bouguer dan Residual yang dikompilasi dengan sesar geologi menunjukkan anomali tinggi berada di baratlaut ke arah Bukit Sibela, utara ke arah Tawa dan tenggara ke arah Gunung Bibinoi sedangkan bagian tengah (Songa dan Wayaua) berupa anomali relatif rendah.

Untuk mencapai sasaran diatas, anomali tinggi di barat laut merupakan respon batuan metamorf yang membentuk Bukit Sibela sedangkan anomali tinggi di tenggara merupakan representasi dari batuan vulkanik produk dari Gunung Bibinoi. Bagian tengah (Songa-Wayaua) merupakan zona endapan hasil erosi dari daerah perbukitan tinggi (Sibela dan Bibinoi) sehingga nilai anomali gaya berat di daerah tengah ini direspon dengan nilai anomali yang relatif lebih rendah dari sekitarnya. Perbedaan densitas batuan yang menyusun daerah sisi tenggara dan baratlaut ini terlihat jelas pada anomali regional yang menunjukkan anomali tinggi di kedua sisi tersebut dan rendah di bagian tengah.

Anomali Bouguer dan residual di sekitar manifestasi panas bumi di pesisir Teluk Lapan (Padopado, Pelepele Besar, Babale Lansa) berada pada nilai rendah Anomali ini sebagai respon batuan yang telah terkekarkan akibat struktur geologi yang berkembang di zona ini yaitu Patahan Pele dan Lapan. Hal ini juga dimungkinkan akibat batuan yang terubahkan karena pengaruh fluida panas yang diindikasikan dengan banyaknya manifestasi panas bumi di daerah tersebut.

Zona anomali rendah di sekitar komplek manifestasi panas bumi Pelepele dan Babale Lansa tersebut terlihat jelas dalam model hasil inversi 3-D dari anomali residual (Gambar 6 dan 7). Batuan ubahan yang ditandai dengan densitas rendah berada di sekitar manifestasi Babale Lansa dan Pelepele yang terdeteksi dari permukaan sampai kedalaman sekitar 500 meter dari permukaan laut. Densitas mulai meninggi kembali yang diperkirakan merupakan zona batas resevoir sedangkan densitas tinggi berupa spot-spot dari pemodelan mengindikasikan tubuh dari Bukit Lansa, Pele dan Gunung Sibela. Struktur geologi berupa sesar yang diperkirakan mengkontruksi sistem panas bumi dan mengontrol munculnya

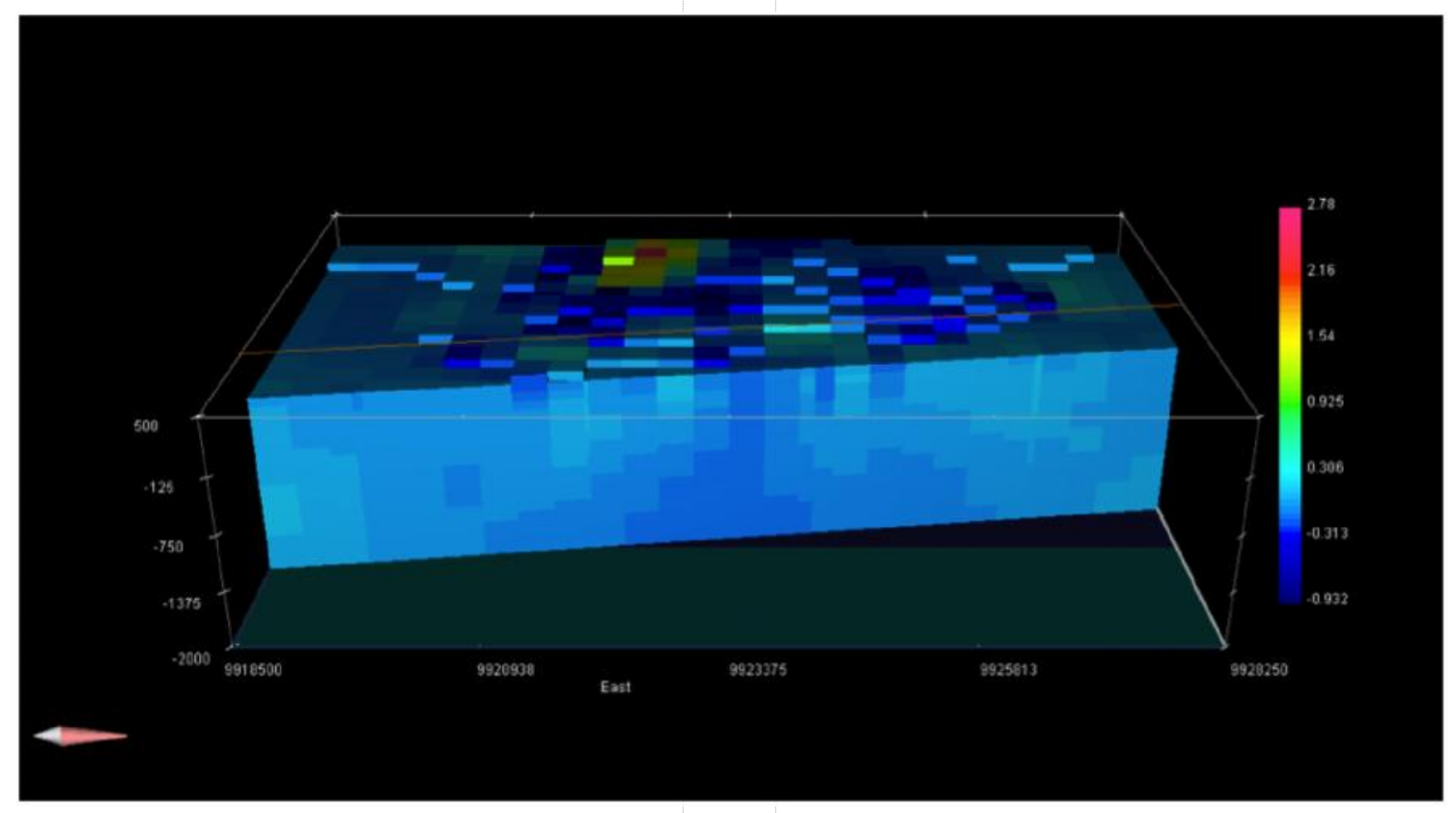

Gambar 6. Penampang model gaya berat berarah hampir tenggara-baratlaut 


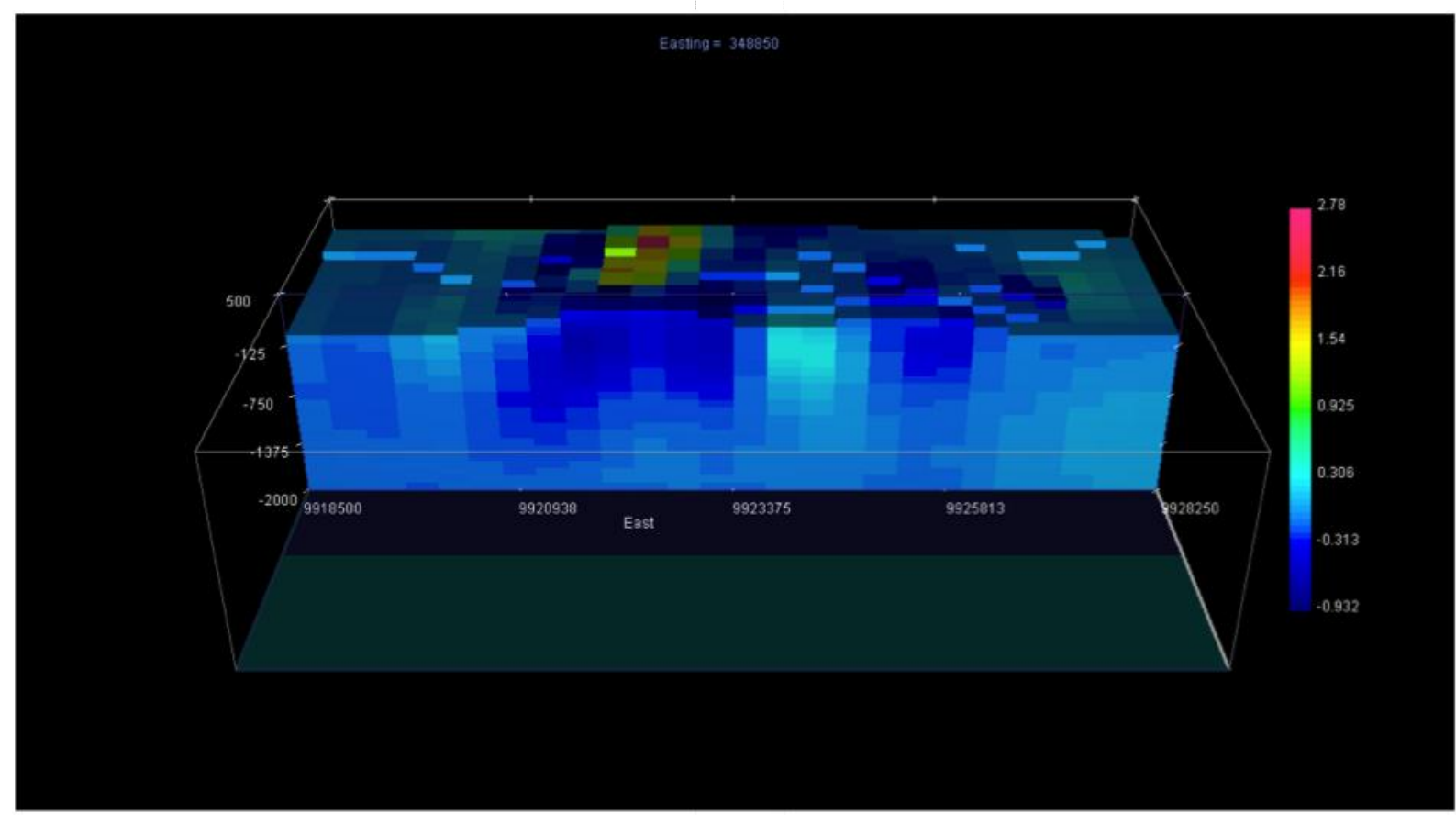

Gambar 7. Penampang model gaya berat berarah Selatan-Utara $(x=348850)$

manifestasi panas bumi adalah Sesar Pele yang berarah baratdaya-timurlaut dan berada di antara Bukit Lansa dan Pele.

\section{PEMBAHASAN}

Data geologi daerah Panas Bumi Songa-Wayaua menunjukkan adanya batuan yang memiliki sifat impermeable dengan kandungan mineral lempung argilik (argilic clay) yang cukup tinggi pada daerah ubahan di sekitar air panas. Zona ubahan ini dicerminkan oleh anomali densitas rendah dari model hasil inversi 3-D dari anomali Residual di sekitar manifestasi Babale Lansa, Pelepele dan Padopado. Anomali ini diinterpretasikan sebagai lapisan batuan ubahan akibat interaksi fluida panas dengan batuan di sekitarnya yang tersebar dari utara ke selatan melewati mata air panas Padopado, Pelepele dan Babale Lansa. Tebal lapisan batuan ubahan ini diperkirakan lebih dari 500 meter yang berperan sebagai lapisan penudung yang dapat menahan fluida panas didalam reservoir.

Batuan yang memungkinkan sebagai pembentuk reservoir diduga pada batuan Metamorf Sibela yang dicerminkan oleh nilai densitas $2.83 \mathrm{gr} / \mathrm{cm}^{3}$. Batuan ini telah mengalami proses deformasi sehingga memungkinkan membentuk pola rekahan yang intensif dan bersifat permeabel.

Batas atas reservoir dari pemodelan inversi 3-D terlihat tren lapisan batuan dengan densitas meninggi mulai kedalaman $>750$ meter. Diperkirakan mulai kedalaman tersebut merupakan zona batas lapisan penudung dan reservoir. Dibagian timur laut reservoir dibatasi oleh sesar Wayaua yang terlihat pada model ini, sedangkan bagian baratdaya diperkirakan dibatasi oleh batas litologi antara batuan metamorf dan granit serta sesar yang berarah relatif sama dengan sesar Wayaua dibawah manifestasi Padopado, walaupun tidak tercermin pada model. Sumber panas (heat sources) untuk sistem panas bumi Songa-Wayaua dicirikan oleh anomali tinggi yaitu dibawah Bukit lansa dan Pele.

\section{KESIMPULAN}

Pemodelan gaya berat inversi 3-D dapat digunakan sebagai acuan dalam menginterpretasi sistem panas bumi di daerah Songa-Wayaua. Hasil pemodelan menunjukkan lapisan penudung yang dicerminkan oleh anomali densitas rendah 


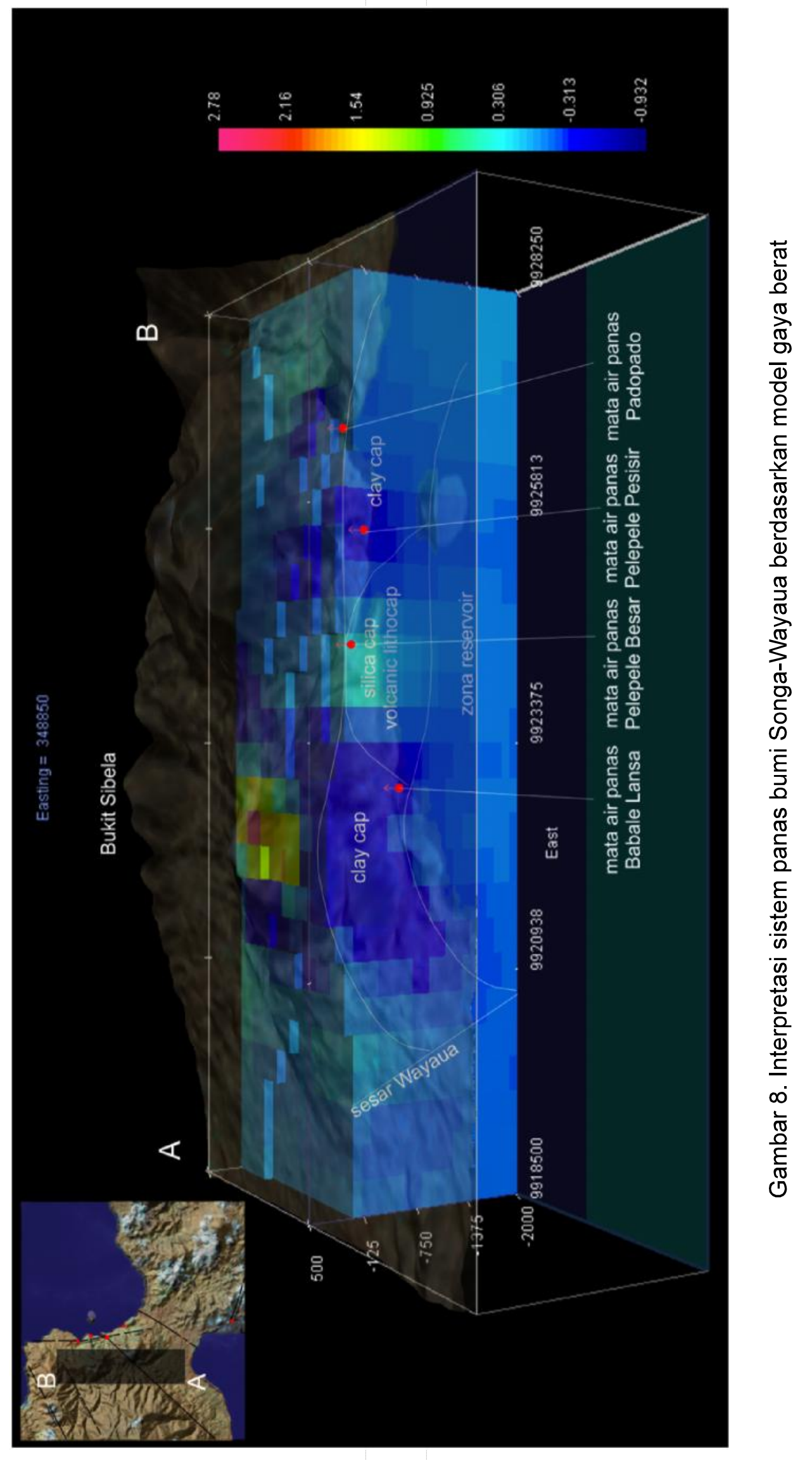


ditemukan di sekitar manifestasi Babale Lansa, Pelepele dan Padopado. Batuan yang memungkinkan sebagai pembentuk reservoir dicerminkan oleh nilai densitas $2.83 \mathrm{gr} / \mathrm{cm} 3$ yang diinterpretasikan mempunyai batas atas reservoir pada kedalaman >750 meter, dengan sisi timur laut dibatasi oleh sesar Wayaua.

Sumber panas (heat sources) dicirikan oleh anomali tinggi yang berada dalam zona anomali rendah yaitu dibawah Bukit lansa dan Pele. Secara geologi kedua tubuh tersebut mencerminkan batuan vulkanik termuda dan diperkirakan menjadi sumber panas pada sistem panas bumi di daerah ini.

\section{UCAPAN TERIMA KASIH}

Penulis berterima kasih kepada tim editor dan dewan redaksi atas saran dan masukan, serta kepada rekan-rekan Pusat Sumber Daya Geologi yang telah membantu penyusunan makalah ini.

\section{DAFTAR PUSTAKA}

Apandi.T, dkk., 1980. Peta Geologi Lembar Ternate, Maluku Utara, Skala 1: 250.000. Pusat Penelitian Dan Pengembangan Geologi. Bandung.

Aquila. L.G.,1977: Magnetic and Gravity surveys Suriagao Geothermal Field, The Comvol letter, v.IV, No 5 \& 6

Burger, H.R., 1992, Exploration Geophysics of shallow Sub Surface, Prentice Hall.

Dobrin, M.B; 1976: Introduction to Geophysical Prospecting. Mc. Grow Hill, p.357-475.

Kadir, W.G.A., 2000, Eksplorasi Gaya Berat dan Magnetik, Jurusan Teknik Geofisika, Fakultas Ilmu Kebumian dan Teknologi Mineral, Institut Teknologi Bandung.

Parasnis, D.S., 1979: Principles of Applied Geophysics, Chapman and Hall,p. 59-96.

Santoso, Djoko, Pengantar Teknik Geofisika, Institut Teknologi bandung.

Telford, W. M., Geldart, L. P., Sheriff, R. E., Keys, D. A., 1990, Applied Geophysics, Cambridge University Press, London.

Tim Survei Terpadu, 2006, Penyelidikan Terpadu Geologi, Geokimia dan Geofisika Daerah Panas Bumi Songa-Wayaua, Pulau Bacan, Maluku Utara, Pusat Sumber daya Geologi, Bandung.

Diterima tanggal 14 Maret 2011

Revisi tanggal 10 April 2011 